\title{
Incorporating World English into ELT in Chinese Universities: Issues and Strategies
}

\author{
Li Gengyan \\ School of Foreign Studies \\ Hubei University of Economics \\ Wuhan, China \\ happylgy@foxmail.com
}

\begin{abstract}
English norm in the Inner Circle countries or specifically the Anglo-American norm has long been viewed as the standard in English language teaching and learning at colleges and universities in China. After introducing English varieties and nativised varieties in particular, the paper presents problems resulting from the tendency in Chinese universities. And then it focuses on how to address these issues: Practices in colleges' deciding on teaching staff, content and methods need to be adjusted; college students' learning objectives and attitude toward English learning should be optimized; the curriculum of English courses should be enriched and accordingly assessment of students' English learning efficiency should be redesigned. However, it has also been noted in the end that reform of English Language Teaching (ELT) in Chinese universities needs not only English teachers' participation but also other forces to take positive roles, such as administrators at colleges and policy makers in the education department.
\end{abstract}

Keywords-World English; English varieties; ELT; Chinese Universities

\section{INTRODUCTION}

According to historical, sociolinguistic and literary contexts, the spread of the English language can be divided into three concentric circles: the Inner Circle where English is local people's native language and there are native English varieties, such as the UK, the US, Canada, Australia, etc., the Outer Circle where English is institutionalized as an additional language and there are nativised English varieties, such as India, Singapore, Malaysia, Ghana, Nigeria, Kenya, etc., and the Expanding Circle where English is used as a foreign language but an increasing use of English is clearly foreseen, such as China, Japan, Israel, Nepal, Saudi Arabia, etc. [1].

English model in Inner Circle countries especially the UK and the US has long been taken as the teaching and learning norm in China since American English and British English are believed as "pure" and "authentic". Other English varieties find it hard to be accepted in Chinese universities although other varieties like Australian English in the Inner Circle and Indian English in the Outer Circle have already gained much popularity. It has been noticed that there is more than one variety even in the UK and the US respectively. Actually nativised variety (like Australian English and Indian English) means a variety has been affected by the local culture and the language of speakers who develop the variety. Acculturation and indigenization can also be used to describe this phenomenon. It should be noted that all the English varieties (including American English and British English) are all nativised English varieties. Therefore, it is insensible to conclude that native speakers from the US or the UK must speak better English than non-native speakers or native speakers must be more suitable for teaching English compared with non-native speakers [2].

It is widely accepted that American English is influential and powerful due to its political power, spread of American culture and media, technological advances and rapid development of communication technology [2], but the belief that American English or British English is superior to other varieties constitutes certain language prejudice. It is regret that this language prejudice is still widespread in Chinese universities not only among students but also among some teachers and administrators. This negative attitude neglects existence of World English (WEs) and poses an obstacle for the advancement of English Language Teaching (ELT) in Chinese universities. Next the issues in ELT relating to this deeply-rooted notion will be clarified and suggestions will also be offered from several aspects including teaching staff, content, methods, learning objective, curriculum design, assessment, etc.

\section{Problems of ELT in Chinese Universities}

Just because of the fallacy of native speakers' advantage over non-native speakers or specifically American and British English speakers' superiority to other native speakers, Chinese universities have shown a strong Inner-Circle orientation in the choice of English teachers. It is often found in terms of foreign teachers' recruitment that Chinese universities are open to declare that they are in want of English teachers from Inner Circle countries. Thus teachers from Outer Circle countries are infrequent in college English classes. It is unimaginable that teachers from Japan, Saudi Arabia or other Expanding Circle countries serve as teaching staff of College English in China. It has been admitted that natives who speak English fluently are not always capable of teaching English or rather teaching Chinese students how to learn English. It is unreasonable or ridiculous to take whether teachers come from Inner Circle countries as the sole standard of recruiting teaching staff.

Textbooks or teaching materials are the other problem. It is a tradition that characters and culture topics in textbooks of 
College English (a compulsory English course or curriculum in most Chinese universities) are mainly from the US and the UK. The roles of recording attached to textbooks or other companion teaching materials are almost performed by American or British speakers. Moreover, students are eager to imitate accents in American or British movies out of their own interests or teachers' guidance. It is easily concluded for Chinese students that it is unacceptable if what they say or hear differs from what they get in the recording of texts or movies that they prefer or teachers recommend. Too much emphasis will undoubtedly hinder these students from improving English proficiency since time and efforts have been paid on mastering accurate accents. On the other hand, topics in texts are restricted in certain countries, which will result in limited vision and lack of global view.

It cannot be denied that many Chinese college students regard a near-native accent as their ultimate learning objective and endeavor to achieve the goal despite the fact that money and energy spent imitating native speakers should have been used more wisely and efficiently. Moreover, some English teachers push their students forward on the road of imitation by regularly recommending some American or British movies out of their own interest.

Finally, changes should also be brought about in the curriculum of ELT and assessment. A few schools of foreign studies in certain universities (e.g. Wuhan University) have offered a course called World English or include relevant information in the current curriculum. However, the target students are usually English majors. What is the attitude of English teachers faced with non-English majors who constitute the major segment of English learning population? Actually these teachers have rarely prepared any resources on World English or English as an International Language (EIL) or English as a Lingua Franca (ELF) all of which are popular topics nowadays and will facilitate students' English learning. On the other hand, teachers tend to evaluate students' English speaking level based on the conviction that non-native students should try every possible means to have native-like pronunciation and intonation.

With so many issues, how to address these challenges will be discussed in the following section from three aspects.

\section{SUGGESTIONS: HOW TO INCORPORATE WORLD ENGLISH INTO ELT}

\section{A. Repositioning Teaching Staff, Content and Methods}

It is pedagogically and morally dangerous to employ untrained native speakers as English teachers. Multilingualism and understanding students' language should be viewed as an important advantage as foreign language teachers for several reasons one of which states that multilingual teachers have experience of learning the language that they are teaching, they can easily realize potential difficulties that their students may encounter, and they are prone to empathize with their fellow people [2]. How should university administrators choose the teaching staff? Should teachers from the Outer Circle countries be privileged just because of their identity of multilingualism?
Should local teachers be preferred since they get familiar with the students?

A pluralistic standard will be advisable. Whether the teachers have received formal training or earned an ELT certificate is the prerequisite of recruitment. Some basic courses can still be offered by local teachers since some students with preliminary and intermediate levels may feel at ease with them. The nature and content of courses is another crucial factor. Courses focusing on English speaking and writing skills would rather consider British or American professionals while courses of English for Specific Purposes (ESP) and culture-related courses should include teachers from the Outer Circle and the Expanding Circle countries since where the teachers were born does not matter under this circumstance.

With regard to teaching materials and methods, it is agreed that stories in the west or the US and the UK in particular are the popular themes in English textbooks and teaching materials. Moreover, it is always British or American people who shoulder the responsibility of recording the texts. On the other hand, teachers often suggest that students play the recording over and over again and imitate what they hear when necessary. However, listening and speaking skills of Chinese students have yet to be improved dramatically. In the globalized world, knowledge about other nations and people are so urgent for cross-cultural communication that topics of typical characters and culture in the Outer Circle and Expanding Circle countries should be added to the present learning materials. It is also suggested that students purposefully try to get access to English movies with actors and actresses from different parts of the world and listen to recording with characters and stories in real life such as the English speaking test of IELTS or TOFEL In addition, to ensure intelligibility of students' English is as important as to comprehend other speakers' English with diverse accents [3].

\section{B. Redirecting Students' Learning Objective}

It has been found that many Chinese make great effort to achieve near-native accent, which is even regarded as an essential goal of English learning. Too much emphasis on accent diverts their attention from the ultimate goal of foreign language learning - easy communication with people from all over the world.

Years of listening to the recording played by American or British people are not conducive to practical listening effects since few people in the physical world speak standard American or British English. Even some natives from the US and the UK cannot attain it, much less people from the Outer and Expanding Circles. With the globalization of economy, politics and culture at present, Chinese get ease access to people with different native languages except English. It is easily found that English serves as the medium for international communication and people all carry different degrees of accent due to transfer of native language.

Some students reject other English varieties and are afraid of interference of non-natives' English accents which are believed to affect purity of their own English accent. Nevertheless, it has been proved that English users will not 
increase their problems in cross-cultural communication if they intentionally get familiar with more English varieties [4]. One way to get students exposed to various varieties in classroom is to introduce speakers of different varieties [5]. Specifically the more familiar speakers (natives or non-natives) are with certain English variety, the more easily they understand members of this language community and are understood by them. Understanding is a two-way communication, which should involve interaction between two parties instead of focusing on either party (speakers or listeners) [4].

Furthermore, localized English varieties borrow words from the local language to describe the local natural phenomenon or culture. The way that English varieties take words from the present English vocabulary to express different meanings or produce different usage will reflect the uniqueness of local culture [2]. Teachers and students should learn to use English to talk about politics, economy and culture in the past and at present in China, which will improve students' interest in English learning and practicability of teachers' instruction. English learners in China should be well prepared to interact with people with all kinds of accents such as Japanese accent, Arabian accent or Spanish accent. It is unnecessary for Chinese students to feel annoyed or humble for their Chinese accent [6].

It should be encouraged when students find profound beauty in other cultures while learning the knowledge about the world through the English language. In Singapore, language policy specifies that all people speak English and their native language such as Chinese Mandarin, Malay and Tamil, which is called "English plus one" bilingual language policy [2]. This bilingual policy can also cater for citizens in China.

\section{Redesigning the Curriculum and Assessment}

It is pointed out that incorporating world English into ELT increases the current repertoire and enriches the curriculum [5].

A course called World English or WEs-related courses need to be included in the curriculum of English at colleges in China. They not only help Chinese learners focus on the development of the English language with a transdisciplinary perspective but also open their minds to other subjects and fields such as creativity of bilingualism, cross-cultural communication strategies, language acquisition, language in the society, etc. [1], which will contribute to broadening their visions, developing their critical thinking abilities and strengthening their adaptive capabilities since more language phenomena need to be viewed from a neutral standpoint.

Teaching of World English not only is academically challenging but also offers a refreshing perspective for the theory and applied research of cross-culture studies while cross-cultural communication is indispensable to English learning [7].

Some English teachers, whether natives or non-natives, mistakenly regard English varieties as errors or mistakes, or regard these non-native varieties as certain interlanguage toward native English [8]. More exposure to these varieties and WEs-related knowledge will lead Chinese students to shape an objective attitude toward their English and others' English. On the other hand, some errors and mistakes in English speaking and writing can be rectified with knowledge of WEs-related theories. For example, common usage of non-native speakers different from Anglo-American speakers will demonstrate that English students in China and other English learners have a lot in common, such as the tendency of omission of articles necessary in natives' language and insertion of articles unnecessary for English natives. It is of no necessity for Chinses students to spend too much time reviewing these points since they do not hinder leaners' successful communication [9].

Last but not least, assessment also needs to be adjusted. Although it has been suggested that assessment of students' English learning should depend on effectiveness of communication instead of grammatical accuracy based on American or British norm [5], the nature of courses is another determining factor. For example, English courses to develop certain writing skills like College English Writing or Academic English should still conform to the traditional English grammatical rules while College English Listening and Speaking or Business English should put emphasis on the content rather than the form of the English language.

\section{CONCLUSION}

Problems with the present ELT in China have gained more attention from different sectors of education-related fields and even the general public. It is proposed that urgent measures be taken to transcend obstacles. Thus some concrete strategies of reform have been offered here but more parties like administrators at colleges and policy makers in the education department rather than ordinary teachers should take more positive and active roles in this reform. Moreover, popularity and recognition of WEs-related concepts needs support from the public media and the society as a whole.

\section{REFERENCES}

[1] Kachru, Braj B. "World English: approaches, issues and resources". Language Teaching, 1992: 25(1), pp. 1-14.

[2] Kirkpatrick, Andy. World English: Implications for International Communication and English Language Teaching. Cambridge: Cambridge University Press, 2007: 8-9, 55, 186-187, 72, 121.

[3] Wen, Qiufang. "A pedagogical model for the teaching of English as an international language"(In Chinese). Curriculum, Teaching Material and Method. 2012: 32(1), pp. 77-81.

[4] Smith, Larry E. Spread of English and Issues of Intelligibility. In Braj B. Kachru (ed.). The other tongue: English across Cultures, 2nd edition, Urbana and Chicago: University of Illinois Press, 1992, pp. 75-90.

[5] Matsuda, Aya. "Incorporating World English in Teaching English as an International Language”. TESOL Quarterly, 2003: 37(4), pp. 719-729.

[6] Meng Zhen \& Yu Zhengting. "China English and English Teaching”(In Chinese). Shandong Foreign Language Teaching, 2003: 1, pp. 9-11.

[7] Kachru, Braj B. "Teaching World English". In Braj B. Kachru (ed.). The other tongue: English across Cultures, 2nd edition, Urbana and Chicago: University of Illinois Press, 1992, pp. 355-365.

[8] Strevens, Peter. "English as an International Language: Directions in the 1990s". In Braj B. Kachru (ed.). The other tongue: English across Cultures, 2nd edition, Urbana and Chicago: University of Illinois Press, 1992, pp. 27-47.

[9] Seidlhofer, Barbara. "Research Perspectives on Teaching English as a Lingua Franca". Annual Review of Applied Linguistics, 2004:24, pp. 209-239. 